\title{
Determination of diet in Manila clams by spatial analysis of stable isotopes
}

\author{
C. Dang ${ }^{1,2, *}$, P. G. Sauriau ${ }^{3}$, N. Savoye ${ }^{1,2}$, N. Caill-Milly ${ }^{4}$, P. Martinez ${ }^{5,6}$, \\ C. Millaret ${ }^{1,2}$, J. Haure ${ }^{7}$, X. de Montaudouin ${ }^{1,2}$ \\ ${ }^{1}$ Université de Bordeaux and ${ }^{2}$ CNRS, UMR 5805, Station Marine d'Arcachon, 2 rue du Pr Jolyet, 33120 Arcachon, France \\ ${ }^{3}$ LIENSs, Université de La Rochelle, CNRS, 2 rue Olympe de Gouge, 17000 La Rochelle, France \\ ${ }^{4}$ IFREMER, Laboratoire Ressources Halieutiques Aquitaine, 1, allée du parc Montaury, 64600 Anglet, France \\ ${ }^{5}$ Université de Bordeaux and ${ }^{6}$ CNRS, UMR 5805, Avenue des Facultés, 33405 Talence, France \\ ${ }^{7}$ IFREMER, Laboratoire Génétique et Pathologie, Polder des Champs, 85230 Bouin, France
}

\begin{abstract}
Spatial changes in the dietary regime of Ruditapes philippinarum from intertidal sediments of Arcachon Bay were depicted by analyzing stable isotope ratios in both its adductor muscles and potential trophic sources. Manila clams were collected from 50 sites in May to June 2006. Dietary reconstruction was based on the IsoSource mixing model, considering trophic enrichments of 3.5\% for carbon and $3.0 \%$ for nitrogen, which were determined experimentally. $\delta^{13} \mathrm{C}$ and $\delta^{15} \mathrm{~N}$ values, respectively, averaged -28.2 and $5.2 \%$ for riverine particulate organic matter (POM), -20.6 and $4.7 \%$ for inner bay phytoplankton, -21.0 and $5.6 \%$ for outer bay phytoplankton, -16.8 and $4.8 \%$ for microphytobenthos, -18.4 and $3.9 \%$ for sedimentary organic matter (SOM) and 11.8 and $4.0 \%$ o for Zostera noltii. Clam muscle $\delta^{13} \mathrm{C}$ and $\delta^{15} \mathrm{~N}$ values ranged from -20.5 to $-16.4 \%$, and from 7.6 to $9.3 \%$, respectively. $\delta^{15} \mathrm{~N}$ significantly decreased from southern to northern parts of the bay, while $\delta^{13} \mathrm{C}$ values increased with tidal elevation. Outer bay phytoplankton was the major diet component of clams. Clams from the southeast mainly incorporated outer bay phytoplankton despite the proximity of the Leyre River, whereas clams from the northwest incorporated approximately equal parts of inner and outer bay phytoplankton, riverine POM, microphytobenthos and SOM. These patterns were consistent with spatial gradients driven by the dominant role of tidal hydrodynamics within the bay and land-use characteristics of the catchment.
\end{abstract}

KEY WORDS: Ruditapes philippinarum $\cdot$ Muscle $\cdot \mathrm{C}$ and N stable isotopes $\cdot$ Trophic sources $\cdot$ Mixing model $\cdot$ Spatial variability $\cdot$ Arcachon Bay $\cdot$ SW France

\section{INTRODUCTION}

The Manila clam Ruditapes philippinarum is native to the Indo-Pacific region and is one of the most fished and farmed bivalves in the world (Gosling 2004). The Manila clam was deliberately introduced into European waters, first in France for culture in 1972 and later in England, Spain and Italy (Flassch \& Leborgne 1992). Within a few years, the species established wild populations in most of these European countries. In Arcachon Bay (SW France), the Manila clam was introduced in 1980 primarily for aquaculture. Due to successful reproduction, it rapidly colonized intertidal areas including Zostera noltii seagrass beds (Blanchet et al. 2004). Today, the species supports intensive commercial fisheries (Caill-Milly et al. 2006). Successive stock assessments of the Manila clam population revealed large heterogeneity in shell length frequency distributions over Arcachon Bay (Caill-Milly et al. 2006). Since the growth of Manila clam depends mainly on temperature and pelagic food sources (Langton et al. 1977, Mann 1979), spatial heterogeneity in both phytoplankton primary production (Glé et al. 2008) and benthic habitats (Blanchet et al. 2004) could lead to spatial heterogeneity in both its demography and growth performances. Furthermore, as the 
wild $R$. philippinarum population represents the second most prevalent suspension-feeder stock in Arcachon Bay, it is expected to play a key role in both the benthic food web and benthic-pelagic coupling within the bay.

Stable isotope analysis has been used widely to investigate time-integrated dietary patterns of organisms and transfers of organic matter within food webs (Peterson \& Fry 1987, Post 2002). $\delta^{13} \mathrm{C}$ helps to identify primary food sources assimilated by consumers, whereas $\delta^{15} \mathrm{~N}$ is used to determine their trophic position (DeNiro \& Epstein 1978, 1981, Post 2002). $\delta^{13} \mathrm{C}$ and $\delta^{15} \mathrm{~N}$ in an organism respectively reflect the $\delta^{13} \mathrm{C}$ and $\delta^{15} \mathrm{~N}$ of its diet with a trophic enrichment $\left(\delta_{\text {consumer }}-\right.$ $\delta_{\text {diet }}$ ) estimated to average 0.5 to $1 \%$ for $\delta^{13} \mathrm{C}$ (DeNiro \& Epstein 1978, Peterson \& Fry 1987) and 3 to $4 \%$ for $\delta^{15} \mathrm{~N}$ (DeNiro \& Epstein 1981, Post 2002). However, these average values hide large variations among species (Peterson \& Fry 1987), feeding modes (McCutchan et al. 2003) and, as organisms are often analyzed whole, highly significant differences between their different tissues (Vanderklift \& Ponsard 2003). For instance, Stephenson \& Lyon (1982), Lorrain et al. (2002) and Malet et al. (2007) reported $\delta^{13} \mathrm{C}$ differences greater than 2 to $3 \%$ between adductor muscles and digestive glands in suspension-feeding bivalves. An increasing practice in stable isotope studies on marine bivalves has been to analyze the adductor muscle instead of the whole body to depict both temporal (Lorrain et al. 2002, Page \& Lastra 2003, Kasai et al. 2004, Malet et al. 2007) and spatial trophodynamics (Machás et al. 2003, Page \& Lastra 2003). Adductor muscles have slower turnover and much lower lipid contents than other tissues such as gonads and digestive glands (Paulet et al. 2006, Malet et al. 2007), and they are a good indicator of long-term diet (Peterson \& Fry 1987). However, no species- and/or tissue-specific trophic enrichment values are available for bivalves in published reviews (Peterson \& Fry 1987, Vander Zanden \& Rasmussen 2001, Post 2002, McCutchan et al. 2003). Thus, it would be particularly useful to experimentally determine these values when using muscle instead of the whole body approach in tracing organic matter flows through suspension-feeding molluscs (Lorrain et al. 2002, Page \& Lastra 2003, Malet et al. 2007).
The present study focused on large-scale spatial variations in the dietary pattern of the suspensionfeeding bivalve Ruditapes philippinarum living in intertidal areas of Arcachon Bay. $\mathrm{C}$ and $\mathrm{N}$ isotopic ratios of its adductor muscles were determined together with those of its potential trophic sources. Trophic enrichment values for adductor muscle were estimated from a long-term diet-switch experiment with the diatom Skeletonema costatum and dietary inferences were deduced from the IsoSource mixing model. In light of known spatial variations in hydrological features within the bay, variations in dietary patterns of Manila clams are then discussed.

\section{MATERIALS AND METHODS}

Study site. Arcachon Bay $\left(44^{\circ} 40^{\prime} \mathrm{N}, 1^{\circ} 10^{\prime} \mathrm{W}\right)$ is a $156 \mathrm{~km}^{2}$ semi-sheltered lagoon located on the southwest coast of France (Fig. 1). Tidal flats extend over $110 \mathrm{~km}^{2}$, of which $70 \%$ are covered by dense Zostera noltii seagrass beds (Auby \& Labourg 1996). Although $Z$. noltii meadows appeared homogeneous, macrozoobenthic community analysis revealed the existence of 4 distinct macrobenthic communities (Blanchet et al. 2004). The main forcing variables such as water mass characteristics and sediment grain-size are under the

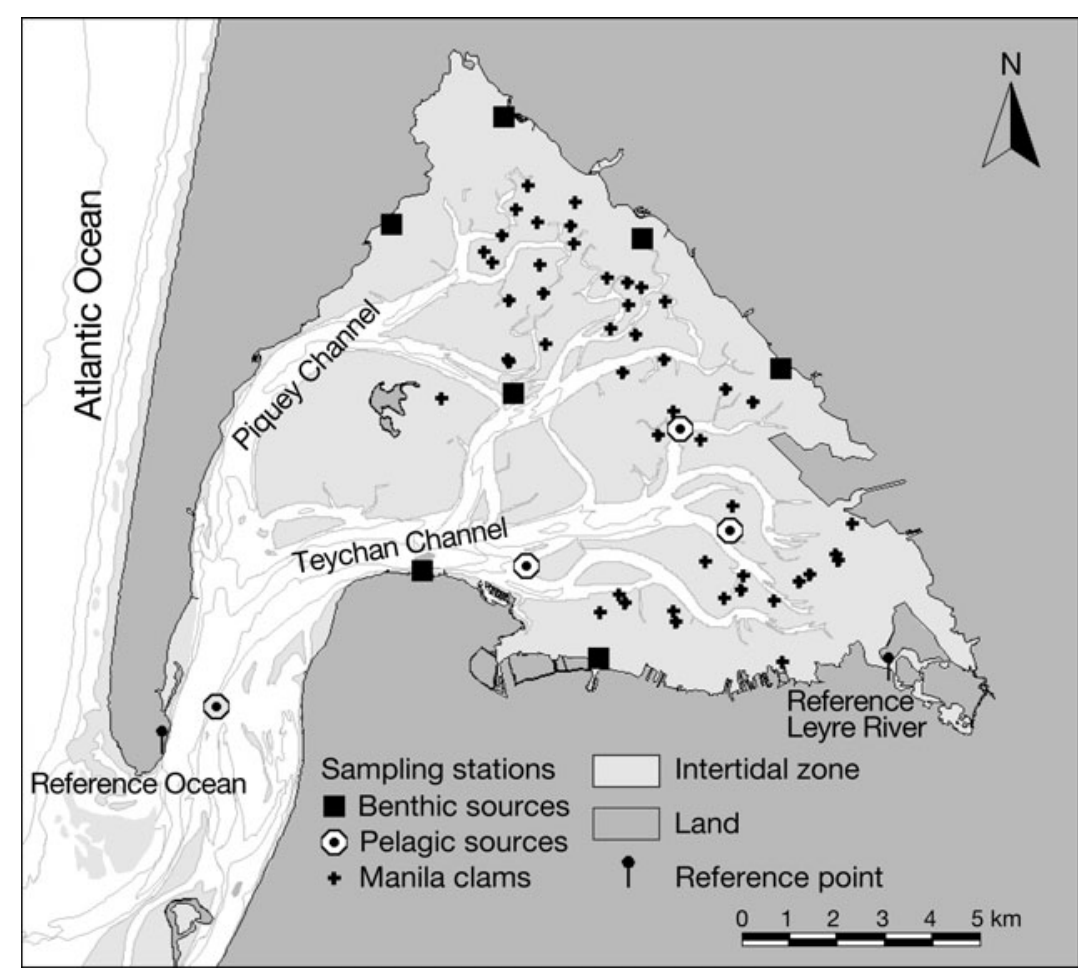

Fig. 1. Arcachon Bay, southwest France, showing location of sampling stations for benthic sources, i.e. sediment, Zostera noltii and microphytobenthos (ם), pelagic sources (•) and Manila clams Ruditapes philippinarum (+) 
control of tidal hydrodynamics (Auby \& Labourg 1996, Blanchet et al. 2004). Arcachon Bay is influenced by both oceanic and continental sources following a semidiurnal macrotidal rhythm. Neritic waters enter the inner lagoon through 2 channels, the Piquey Channel which extends to the north and the larger Teychan Channel at the south (Fig. 1). The seawater exchange ranges from $160 \times 10^{6}$ to $400 \times 10^{6} \mathrm{~m}^{3}$ per tide following the spring to neap tide cycle, and meets freshwater inputs coming principally from the Leyre River in the east. According to Direction Régionale de l'Environnement (DIREN) data, Leyre River discharge during 2006 was low compared to its average 20 yr discharge, and the maximum runoff was $25 \mathrm{~m}^{3} \mathrm{~s}^{-1}$ in March 2006. The remaining freshwater inputs are provided by 17 secondary streams and diffuse sources located on the eastern side of the lagoon (De Wit et al. 2005). Sediment grain-size in $Z$. noltii beds varies from mud to sandy mud (Blanchet et al. 2004). Clams were usually located near the mid-tidal level within seagrass meadows (Caill-Milly et al. 2006). The Manila clam habitat in Arcachon Bay appears to be a mosaic of sedimentary biofacies where salinity and sediment temperature fluctuate yearly between 4 and 35 , and between -2 and $44^{\circ} \mathrm{C}$, respectively (Dang et al. 2008).

Sampling strategy. Manila clams were sampled at 50 geographically referenced stations within Arcachon Bay between mid-May and mid-June 2006 (Fig. 1). Stations were evenly dispersed within the ca. $70 \mathrm{~km}^{2}$ distribution area of the species, as previously described by stock assessment studies (Caill-Milly et al. 2006). Tidal elevation (m) of each station was provided by both Service Hydrographique de la Marine (SHOM, Brest) and Direction Départementale de l'Equipement de la Gironde (DDE, Bordeaux). A total of 3 adult clams ranging from 30 to $36 \mathrm{~mm}$ in shell length were collected at each station.

Prior to the clam sampling (24 April to 15 May 2006), marine and continental water, sediment and benthic primary producers were sampled. Water was collected at 4 stations within Arcachon Bay and at 2 stations in the Leyre River (Fig. 1). Particulate organic carbon (POC) and nitrogen (PON), chlorophyll a (chl a) and $\delta^{13} \mathrm{C}$ and $\delta^{15} \mathrm{~N}$ of particulate organic matter (POM) were then determined. The dominance of phytoplankton within the bulk POM was checked using a POC:chl a ratio of 200 (Cifuentes et al. 1988). When the water column POM exhibited POC:chl a ratios of 80 to 180, samples were used to characterize living phytoplankton. Surface sediment, microphytobenthos and living Zostera noltii leaves were sampled at 7 intertidal stations (Fig. 1). Water was sampled using a Niskin bottle and immediately poured into pre-cleaned plastic bottles before filtration. Surface sediment was sampled directly using acid-cleaned and pre-combusted glass vials. Living Z. noltii leaves were hand-sampled and placed within clean plastic bags.

Long-term diet-switch experiment. Batch cultures of the diatom Skeletonema costatum were kept in outdoor concrete tanks $\left(80 \mathrm{~m}^{3}\right)$ under natural light conditions and continuous aeration (Baud \& Bacher 1990, Sauriau et al. 1997). Salty groundwater pumped up from the subsoil was used as the culture medium since its nutrient composition was recognized to favour $S$. costatum growth (Baud \& Bacher 1990). Diatom cultures in exponential growth phase (i.e. after 3 to $4 \mathrm{~d}$ and with cell concentrations of ca. $1.5 \times 10^{6}$ cells ml $^{-1}$ ) were used as monospecific algal food for rearing clams (Sauriau et al. 1997). Temperature and salinity in the tanks ranged from 15.1 to $19.2^{\circ} \mathrm{C}$, and 32.5 to 32.7 , respectively. The food ration was ca. $2 \times 10^{9}$ algal cells $\mathrm{d}^{-1}$ clam $^{-1}$. Algal isotopic composition was monitored weekly by filtering four 0.51 samples through precombusted Whatman GF/F fiberglass filters $(25 \mathrm{~mm}$ diameter). Filters were then immediately stored at $-20^{\circ} \mathrm{C}$ until freeze-drying.

A total of 100 adult Manila clams were collected from the intertidal mudflats of Ile aux Oiseaux (Arcachon Bay) at the end of May 2006. They averaged $41.1 \pm 1.1 \mathrm{~mm}$ shell length and $0.43 \pm 0.08 \mathrm{~g}$ tissue dry weight. Clams were reared in $500 \mathrm{l}$ tanks for $160 \mathrm{~d}$. They were placed on trays filled with medium to coarse sand allowing them to bury and adopt a natural suspension-feeding behaviour. The flow of underground seawater was controlled in each tank at a rate of $101 \mathrm{~min}^{-1}$ and was continuously aerated; 5 clams were randomly sampled on 1 June 2006 and then 5, 11, 20, 40, 76, 103, 126 and 160 d later. At each sampling date, individual clams were cleaned and placed in an aerated tank with filtered underground seawater for $48 \mathrm{~h}$ to allow gut content evacuation. All sampled clams were subsequently frozen at $-20^{\circ} \mathrm{C}$ until dissection.

Sample processing. Clam shell length was measured by a digital caliper to the nearest $\mathrm{mm}$. Clams were then opened, their posterior adductor muscles dissected, frozen at $-20^{\circ} \mathrm{C}$ for storage and then frozen at $-80^{\circ} \mathrm{C}$ prior to freeze-drying. Water samples were filtered onto $47 \mathrm{~mm} \mathrm{GF/F}$ filters for chl $\mathrm{a}$ and onto pre-combusted $25 \mathrm{~mm}$ GF/F filters for POC, PON, $\delta^{13} \mathrm{C}$ and $\delta^{15} \mathrm{~N}$. Filters for chl a were stored frozen $\left(-80^{\circ} \mathrm{C}\right)$, whereas filters for $\mathrm{C}$ and $\mathrm{N}$ elemental and isotopic analysis were freeze-dried and then stored at room temperature. Sediment samples were frozen at $-20^{\circ} \mathrm{C}$. Zostera noltii leaves were cleaned of their epiphytes, decarbonated in a bath of $2 \% \mathrm{HCl}$ and then rinsed with Q-water (C elemental and isotopic analysis), or only rinsed with $\mathrm{Q}$-water ( $\mathrm{N}$ elemental and isotopic analysis). Leaves were then dried overnight in an oven $\left(60^{\circ} \mathrm{C}\right)$ and stored in aluminum foil at room temperature. Sediment for 
carbon and nitrogen elemental and isotopic analysis was decarbonated using $2 \mathrm{~N} \mathrm{HCl}$ (Kennedy et al. 2005). Filters for carbon and nitrogen elemental and isotopic analysis were decarbonated using $\mathrm{HCl}$ fumes (Lorrain et al. 2003). Prior to analysis, clam muscle and sediment samples were freeze-dried and ground using mortar and pestle to get a homogeneous fine powder. $Z$. noltii leaves were similarly ground.

Sample analysis. Chl a was analyzed by fluorescence (Yentsch \& Menzel 1963). C and N elemental and isotopic analysis were performed using an elemental analyzer (Carlo Erba 2500) in line with an isotope ratio mass spectrometer (VG Isoprim). Data were corrected and calibrated against homemade working standards (casein and glycin) and against certified standards (acetanilide, IAEA-N2, USGS-24). These standards allowed the analytical precision to be set at $0.2 \%$. Isotopic values are reported in the usual per mil unit (\%) following:

$$
\delta^{\mathrm{A} X}=\left[\left(R_{\text {sample }} / R_{\mathrm{ref}}\right)-1\right] \times 1000
$$

where A is the atomic mass of the heavy stable isotope of the element $\mathrm{X}$, and $R_{\text {sample }}$ and $R_{\text {ref }}$ are the ratios of heavy to light isotopes for carbon $\left({ }^{13} \mathrm{C} /{ }^{12} \mathrm{C}\right)$ and nitrogen $\left({ }^{15} \mathrm{~N} /{ }^{14} \mathrm{~N}\right)$. References are Vienna Pee Dee Belemnite (VPDB) for $\delta^{13} \mathrm{C}$ and atmospheric nitrogen for $\delta^{15} \mathrm{~N}$.

Trophic enrichment estimates. Temporal changes in stable isotope ratios exhibited by clam muscles were fitted to the equation proposed by Tieszen et al. (1983): $\mathrm{Y}_{t}=a+b \times \mathrm{e}^{c t}$. In this time-based equation, $\mathrm{Y}_{t}(\%)$ is the $\delta$ ratio of clam tissues at time $t$ (days since the first sampling date), $a(\%)$ is related to the $\delta$ ratio of tissues in equilibrium with the new diet, $b(\%)$ refers to the difference between initial and asymptotic $\delta$ ratio of tissues and $c\left(\mathrm{~d}^{-1}\right)$ is the turnover rate of tissues. All equation parameters were estimated by non-linear regression using SigmaPlot 1.02 (Jandel Scientific). Trophic enrichment values for both $\delta^{13} \mathrm{C}$ and $\delta^{15} \mathrm{~N}$ were then calculated as the difference between the $\delta$ ratios of tissues in equilibrium with the new diet and the average $\delta$ ratios of the diet. The half-life of $\delta^{13} \mathrm{C}$ and $\delta^{15} \mathrm{~N}$ was defined as $\ln \left(0.5 C^{-1}\right)$ in days, and was the time over which $50 \%$ of the isotope ratios were exchanged in the tissue.

Mixing model: IsoSource. Phytoplankton from both the inner and outer bay, Leyre River POM, microphytobenthos, sedimentary organic matter (SOM) and Zostera noltii leaves were considered as potential trophic resources for the Manila clam. Macroalgae were not considered as a potential food source for Ruditapes philippinarum due to their very low prevalence in clam habitat within Arcachon Bay. The IsoSource software (Phillips \& Gregg 2003, Phillips et al. 2005) was used to determine the relative contribution of each source to the mixed signature of clam adductor muscles at the 50 stations sampled. Experimentally determined muscle-specific trophic enrichments for both $\delta^{13} \mathrm{C}$ and $\delta^{15} \mathrm{~N}$ were subtracted from adductor muscle values before IsoSource analysis.

Statistical analyses. Statistical analyses were performed using Statistica 7.1 software (StatSoft). The maximum type I error rate was set at $\alpha=0.05$. Results are expressed as mean $\pm \mathrm{SD}$ with $\mathrm{n}$ equal to the number of samples analyzed. Homogeneity of variance was checked using Cochran's test. First, a nested ANOVA was conducted to compare $\mathrm{C}$ and $\mathrm{N}$ isotopic ratios of the Manila clam muscle between the 50 stations (Sokal $\&$ Rohlf 1981). Second, single linear regressions were computed between $\delta^{13} \mathrm{C}, \delta^{15} \mathrm{~N}$ and the distance $(\mathrm{km})$ of each station from the Leyre River mouth, tidal elevation $(\mathrm{m})$ and clam shell length $(\mathrm{mm})$. Distances from the Leyre River were calculated with the Arcview 3.2 GIS software.

\section{RESULTS}

\section{Trophic enrichment of $\delta^{13} \mathrm{C}$ and $\delta^{15} \mathrm{~N}$}

During the course of the diet-switch experiment, adult Manila clams exhibited a small growth in shell length $(+3.3 \pm 1.1 \mathrm{~mm})$; however, they increased by 3.2- and 2.6-fold in total tissue and adductor muscle dry weight, respectively. At the start of the feeding experiment, carbon and nitrogen isotopic ratios of adductor muscles averaged $-16.7 \pm 0.3$ and $9.2 \pm 0.4 \%$ o $(\mathrm{n}=5)$, respectively. Both $\delta^{13} \mathrm{C}$ and $\delta^{15} \mathrm{~N}$ values of adductor muscles changed toward more depleted values and converged on asymptotic values reflecting the incorporation of the algal diet (Fig. 2). Skeletonema costatum had stable carbon and nitrogen isotopic ratios of $-28.5 \pm 0.8$ and $5.4 \pm 0.6 \%$ o $(\mathrm{n}=45)$, respectively. The exponential decay model provided a good fit to changes in both $\delta^{13} \mathrm{C}$ and $\delta^{15} \mathrm{~N}$ muscle values with significant correlations $\left(\delta^{13} \mathrm{C}: \mathrm{r}=0.96, \mathrm{p}<0.001 ; \delta^{15} \mathrm{~N}: \mathrm{r}=\right.$ $0.63, \mathrm{p}<0.01)$. The trophic enrichment for adductor muscles was $+3.5 \%$ for $\delta^{13} \mathrm{C}$ and $+3.0 \%$ for $\delta^{15} \mathrm{~N}$. The half-life values were 26.8 and $13.3 \mathrm{~d}$ for $\delta^{13} \mathrm{C}$ and $\delta^{15} \mathrm{~N}$, respectively.

\section{Isotopic signatures}

\section{Clam muscle}

Carbon isotopic ratios of muscle tissue sampled at the 50 stations in the bay ranged from -20.2 to $-16.4 \%$ (Fig. 3), owing to significant $\delta^{13} \mathrm{C}$ differences between stations (nested ANOVA, p < 0.001). However, most of the values were scattered around $-17.4 \pm 0.6 \%$. Spatial 



Fig. 2. Ruditapes philippinarum. Changes in (A) $\delta^{13} \mathrm{C}$ and (B) $\delta^{15} \mathrm{~N}$ of the posterior adductor muscle of adult clams during a diet-switch experiment. Mean $\delta^{13} \mathrm{C}$ and $\delta^{15} \mathrm{~N}$ values for the algal diet (- - ) and exponential decay curves $(-)$ are indicated
Table 1. Single regression results between $\delta^{15} \mathrm{~N}, \delta^{13} \mathrm{C}$ and distance to the Leyre River, tidal level and clam shell length

\begin{tabular}{|lrrrrr|}
\hline & \multicolumn{3}{c}{$\delta^{15} \mathrm{~N}$} & \multicolumn{3}{c|}{$\delta^{13} \mathrm{C}$} \\
& $\mathrm{R}^{2}$ & $\mathrm{p}$ & \multicolumn{1}{c|}{$\mathrm{R}^{2}$} & $\mathrm{p}$ \\
\hline Leyre distance $(\mathrm{km})$ & 0.40 & $<0.01$ & 0.01 & 0.58 \\
Tidal level (m) & $<0.01$ & 0.80 & 0.15 & 0.01 \\
Clam shell length (mm) & $<0.01$ & 0.35 & $<0.01$ & 0.41 \\
& & & & & \\
\hline
\end{tabular}

Primary producers and sediment

Stable isotopic ratios of primary producers and sediment in Arcachon Bay are presented in Table 2. POM sampled in the Leyre River was highly depleted in ${ }^{13} \mathrm{C}$ compared to the phytoplankton of the bay. Microphytobenthos had much lighter $\delta^{13} \mathrm{C}$ values than riverine POM and bay phytoplankton but a similar $\delta^{15} \mathrm{~N}$ value compared to inner bay phytoplankton. The scatterplot of stable isotope values of clam muscle tissues corrected for trophic enrichments $\left(\delta^{13} \mathrm{C}: 3.5 \% ; \delta^{15} \mathrm{~N}\right.$ : $3 \%$ ) and potential trophic sources is presented in Fig. 5. With the exception of one station located close to the Leyre River mouth, which was significantly different in $\delta^{13} \mathrm{C}(-23.6 \pm 0.1 \%)$, isotopic values of other stations appeared as a single cluster with $\delta^{13} \mathrm{C}$ ranging from -21.7 to $-19.5 \%$ and $\delta^{15} \mathrm{~N}$ from 4.6 to $6.3 \%$. The scatterplot also highlights the close correspondence between the clam isotopic values corrected for trophic enrichment and those of outer and inner bay phytoplankton. dispersion in $\delta^{13} \mathrm{C}$ values seemed heterogeneous with no evidence of a consistent spatial pattern (Fig. 3). No significant relationships were thus found between $\delta^{13} \mathrm{C}$ and distance to the Leyre River or clam shell length $(\mathrm{p}>0.05)$ (Table 1$)$. However, a significant positive correlation was found between $\delta^{13} \mathrm{C}$ and tidal elevation $(\mathrm{p}<0.05)$ (Table 1).

Nitrogen isotopic ratios of muscle tissues ranged between 7.4 and $9.8 \%$ with a mean value of $8.5 \pm 0.5 \%$ o (Fig. 4). Significant differences in $\delta^{15} \mathrm{~N}$ were observed among stations (nested ANOVA, p < 0.001). The highest clam muscle $\delta^{15} \mathrm{~N}$ values were located at the southeastern part of the bay along the Teychan channel, whereas almost all the low $\delta^{15} \mathrm{~N}$ values were located to the north in the bay (Fig. 4). A negative correlation was observed between $\delta^{15} \mathrm{~N}$ and the distance to the Leyre River $(\mathrm{p}<0.05)$ (Table 1$)$. No significant correlations were found with tidal elevation or clam shell length ( $p>0.05)$ (Table 1).

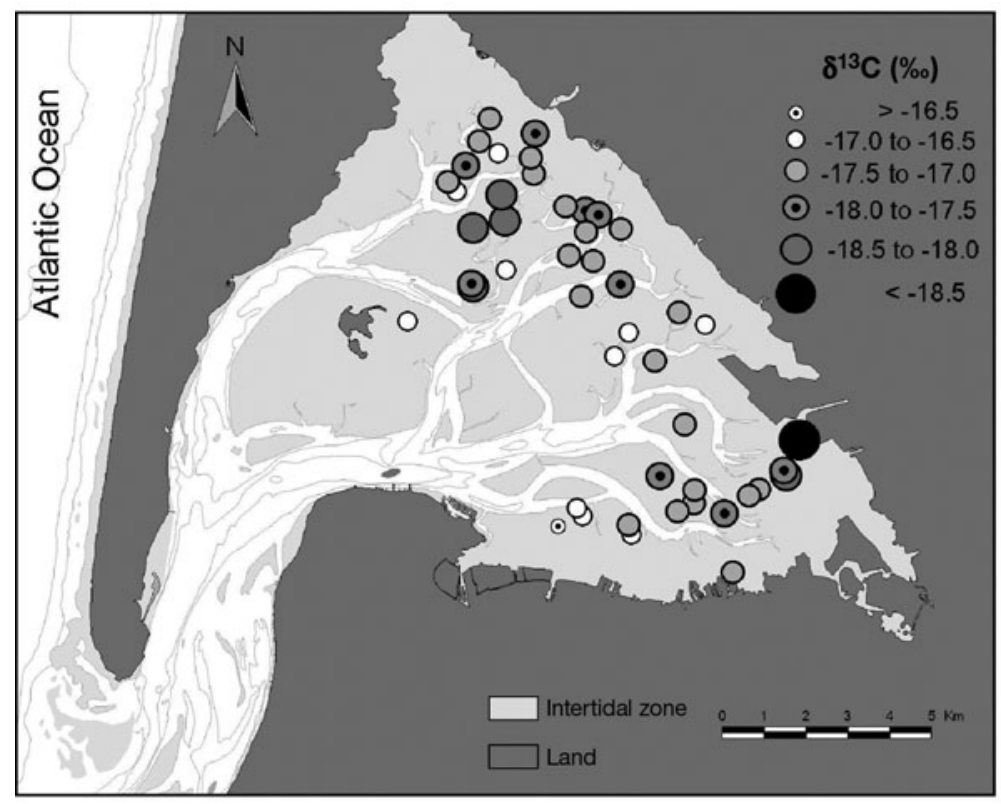

Fig. 3. Ruditapes philippinarum. Spatial variation in carbon isotopic ratios $\left(\delta^{13} \mathrm{C}\right)$ of posterior adductor muscle of adult clams sampled at 50 stations in Arcachon Bay in May-June 2006 


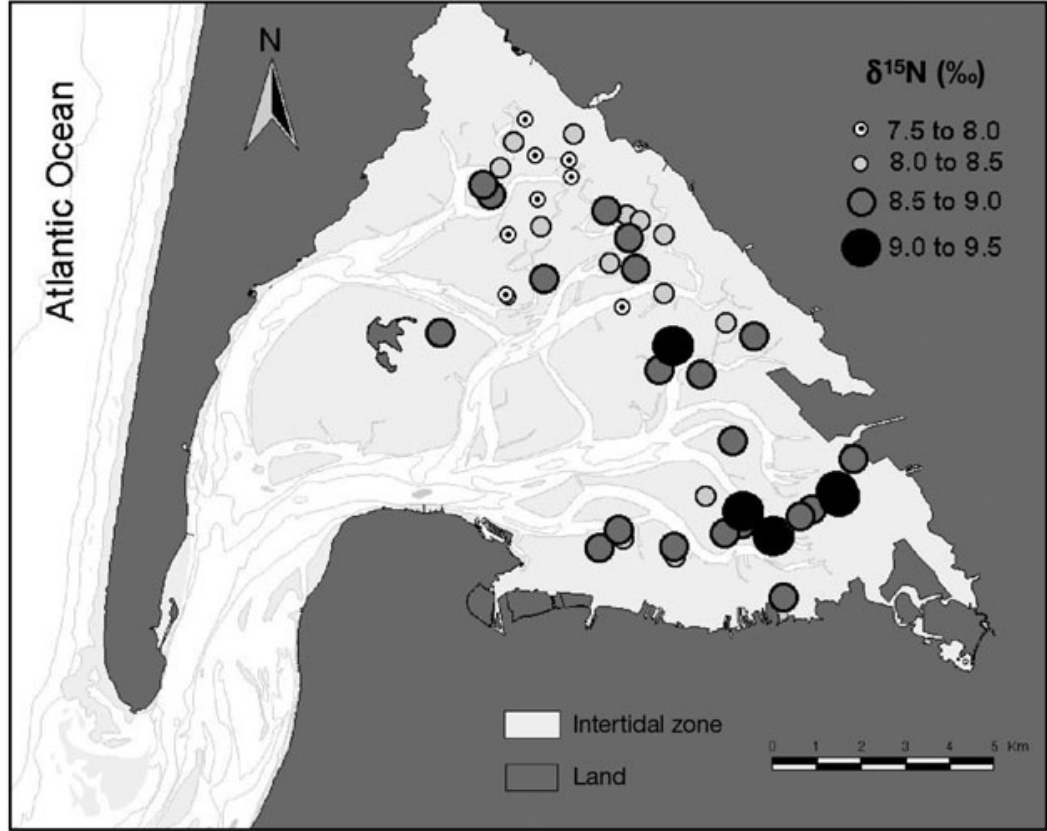

Fig. 4. Ruditapes philippinarum. Spatial variation in nitrogen isotopic ratios $\left(\delta^{15} \mathrm{~N}\right)$ of posterior adductor muscle of adult clams sampled at 50 stations in Arcachon Bay in May-June 2006

Table 2. Carbon and nitrogen stable isotope ratios for primary producers and sediment in Arcachon Bay. $\delta^{15} \mathrm{~N}$ analysis from Pothier \& Savoye (unpubl. data). POM: particulate organic matter

\begin{tabular}{|c|c|c|c|c|}
\hline \multirow[t]{2}{*}{ Potential source } & \multicolumn{2}{|c|}{$-\delta^{13} \mathrm{C}-$} & \multicolumn{2}{|c|}{$-\delta^{15} \mathrm{~N}-$} \\
\hline & Mean \pm SD & $\mathrm{n}$ & Mean $\pm \mathrm{SD}$ & $\mathrm{n}$ \\
\hline Phytoplankton (outer bay) & $-20.96 \pm 1.23$ & 4 & $5.62 \pm 1.39$ & 5 \\
\hline Phytoplankton (inner bay) & $-20.60 \pm 0.42$ & 4 & $4.75 \pm 0.33$ & 11 \\
\hline POM Leyre & $-28.24 \pm 0.10$ & 2 & 5.24 & 1 \\
\hline Microphytobenthos & $-16.81 \pm 2.29$ & 2 & $4.76 \pm 0.55$ & 2 \\
\hline Sedimentary organic matter & $-18.40 \pm 0.26$ & 7 & $3.94 \pm 0.66$ & 7 \\
\hline Zostera noltii leaves & $-11.77 \pm 1.07$ & 7 & $3.99 \pm 1.18$ & 7 \\
\hline
\end{tabular}

Modelling of the Manila clam food sources yielded different proportions of each food source, depending on geographical location (Fig. 6). Clams located in the southern part of the bay along the Teychan Channel assimilated much higher outer bay phytoplankton than clams located to the north. In the northeastern end of the bay, trophic sources of clams were the most diverse: contributions of riverine POM, inner bay phytoplankton, microphytobenthos and SOM were higher than for clams collected in the south. The riverine POM contribution was sometimes higher than that of outer bay phytoplankton, and the contribution of Zostera noltii to the clam diet was low and never exceeded $9 \%$.

\section{DISCUSSION}

\section{Trophic enrichment in Manila clam muscle}

Trophic enrichment in ${ }^{13} \mathrm{C}$ and ${ }^{15} \mathrm{~N}$ of consumers relative to their diet is consistently reported in stable isotope analyses (DeNiro \& Epstein 1978, 1981, Peterson \& Fry 1987). The trophic enrichment for $\delta^{13} \mathrm{C}$ experimentally found in the adductor muscle of Manila clams (3.5\%) was much higher than the average values of $0.8 \pm$ 1.1 and $0.47 \pm 1.23 \%$ o given for whole body organisms by DeNiro \& Epstein (1978) and Vander Zanden \& Rasmussen (2001), respectively. However, variations existed among species as

\section{Food source analysis: IsoSource}

The IsoSource mixing model estimated that, at the bay scale, phytoplankton contributed most (63\% on average) to the diet of Manila clams. Outer bay phytoplankton contributed the most $(50 \pm 27 \%)$, followed by riverine POM $(16 \pm 9 \%)$ and inner bay phytoplankton $(14 \pm 10 \%)$. The proportions of microphytobenthos, SOM and Zostera noltii to the clam diet were $9 \pm 5,7 \pm 5$ and $5 \pm 3 \%$, respectively. Excluding Zostera noltii as a potential food source from the mixing model does not affect these values since contributions of outer bay phytoplankton, riverine POM, inner bay phytoplankton, microphytobenthos and SOM were $52 \pm 25,12 \pm 8$, $15 \pm 8,12 \pm 6$ and $9 \pm 6 \%$, respectively. $\delta^{13} \mathrm{C}$ trophic enrichment values ranged from -3 to $+3.5 \%$ (Post 2002). Yokoyama et al. (2005a) reported an experimentally determined trophic enrichment of $0.6 \%$ for $\delta^{13} \mathrm{C}$ in whole body of Ruditapes philippinarum juveniles. Highly significant variations have also been reported among tissues within species, and McCutchan et al. (2003) reported a higher trophic shift for consumers analysed as muscle $(+1.3 \pm 0.3 \%$ o) than for consumers analyzed whole $(+0.3 \pm 0.1 \%)$. Tissuespecific differences in trophic enrichment are linked to biochemical compounds (DeNiro \& Epstein 1978) and pathways by which compounds are metabolized in and/or routed to different tissues (Gannes et al. 1997). Lipids are depleted in ${ }^{13} \mathrm{C}$ compared to carbohydrates and proteins (DeNiro \& Epstein 1978). Since lipid con- 


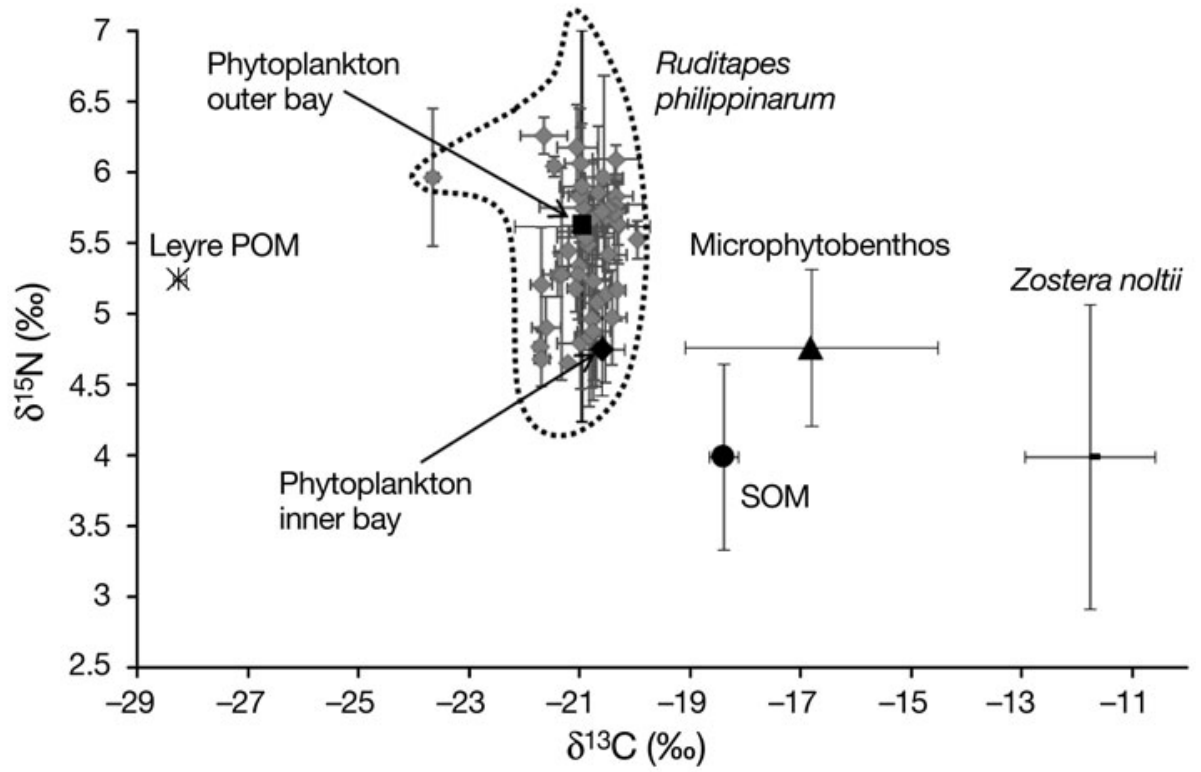

Fig. 5. Ruditapes philippinarum. $\mathrm{N}$ vs. C stable isotope ratios (mean $\pm \mathrm{SD}$ ) of posterior adductor muscles of clams sampled at 50 stations (corrected for trophic shift; $\diamond$ ) and trophic sources potentially consumed as inner bay phytoplankton-dominated particulate organic matter (POM; ), outer bay phytoplankton-dominated POM (ם), Leyre POM $(*)$, microphytobenthos $(\mathbf{\Delta})$, sediment $(\boldsymbol{\bullet})$ and Zostera noltii (-). The area enclosed by the dotted line corresponds to the expected $\delta^{13} \mathrm{C}$ and $\delta^{15} \mathrm{~N}$ of the food resources incorporated by the Manila clam in its adductor muscle, as deducted from trophic shifts of 3.5 and $3 \%$ for $\delta^{13} \mathrm{C}$ and $\delta^{15} \mathrm{~N}$, respectively tents are much lower in muscle tissues than in gonads and digestive glands of bivalves (Lorrain et al. 2002, Malet et al. 2007), muscles typically are enriched in ${ }^{13} \mathrm{C}$ relative to other lipid-rich organs.

To our knowledge, tissue-specific $\delta^{13} \mathrm{C}$ trophic enrichment has never been estimated for marine bivalves, despite recent experimental studies by Yokoyama et al. (2005a), Paulet et al. (2006) and Dubois et al. (2007). Our experimental results are in accordance with Paulet et al. (2006) and field studies which analyzed tissue-specific trophodynamics in bivalves (Stephenson \& Lyon 1982, Lorrain et al. 2002, Malet et al. 2007). In these studies, differences in $\delta^{13} \mathrm{C}$ between adductor muscles and digestive glands ranged from +1.8 to $+5.5 \%$, depending on the species and season. A similar range $(+1.4$ to $+2.5 \%$ ) was reported by Page $\&$ Lastra (2003) between adductor muscle and gut contents of Ruditapes decussatus. As $\delta^{13} \mathrm{C}$ in digestive glands reflects the assimilated diet with a low trophic enrichment, dietary reconstruction from adductor muscle of bivalves should use new $\delta^{13} \mathrm{C}$ trophic enrichment values instead of the average values given in the literature. However, new estimates are required for bivalves other than $R$. philippinarum. The weight-to-weight proportion of clam adductor muscles versus whole body was constant over the feeding experiment and averaged $15.8 \pm 2.3 \%$ (authors' unpubl. data, dietswitch experiment). Assuming that the weighted average of the isotopic composition of all organs equals the isotopic composition of the whole body (see equation in Lorrain et al. 2002), the utilization of the trophic enrichment of $3.5 \%$ for carbon in muscle with a trophic enrichment of $0.5 \%$ for carbon in whole body Manila clams (Yokoyama et al. 2005a) would indicate a 0.1 to $0.3 \%$ trophic enrichment for carbon in all remaining tissues. This mass-balance analysis suggests that a $>3 \%$ muscle-specific $\delta^{13} \mathrm{C}$ trophic enrichment may be consistent with $<1 \%$ o $\delta^{13} \mathrm{C}$ trophic enrichment for whole body in Manila clams.

In contrast to carbon, the trophic enrichment of $3 \%$ in $\delta^{15} \mathrm{~N}$ from the diatom Skeletonema costatum to Manila clam during the diet-switch experiment was in the range of the 3 to $4 \%$ given by Peterson \& Fry (1987). This was consistent with the average values provided by Post (2002) (3.4 $\pm 1 \%$ ) and McCutchan et al. (2003) $(2.9 \pm 1.2 \%$ ) for muscle tissues of a large variety of consumers.

\section{Spatial variation in $\delta^{13} \mathrm{C}$ and $\delta^{15} \mathrm{~N}$ of Manila clams}

Variation in carbon isotopic ratios of clam adductor muscles were lower than $4 \%$ and ranged from -23.7 to $-19.9 \%$ for values corrected for trophic enrichment. Contrary to what could be expected from depleted $\delta^{13} \mathrm{C}$ Leyre River POM (Table 1 ) and the spatial extent of its low salinity plume on most of the clam habitat during winter (Bouchet 1993), lack of significant correlation between $\delta^{13} \mathrm{C}$ clam muscle and distance to the Leyre River suggested no or low contributions of riverine materials to the diet of clams. Clam muscles, as slow growing tissues, should reflect the isotope composition of food assimilated during their growth season, from April to July in Arcachon Bay (Robert et al. 1993). Since clams in the present study were sampled from mid-May to mid-June, and the half-time of $\delta^{13} \mathrm{C}$ was estimated at ca. $1 \mathrm{mo}$, this suggests that clam muscles have integrated food variability for the end of winter. However, the period between early April and June was characterized by low Leyre River runoffs with 


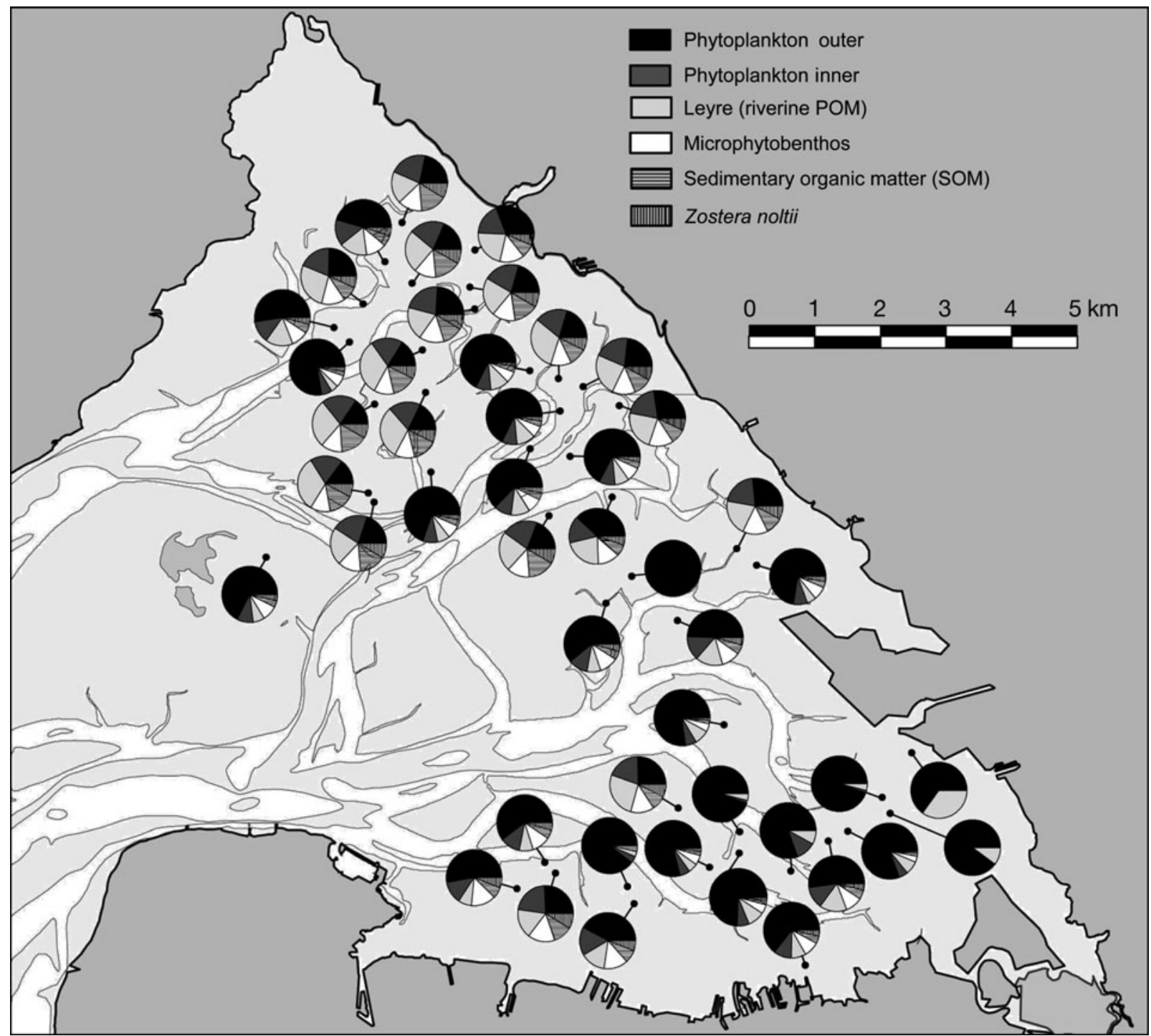

Fig. 6. Ruditapes philippinarum. Predicted spatial variation in the proportion of trophic sources for adult clams within Arcachon Bay. Trophic sources considered are outer bay phytoplankton, inner bay phytoplankton, riverine particulate organic matter (POM; Leyre River), microphytobenthos, sedimentary organic matter and Zostera noltii. The black circle bound to each pie represents the position of the sampled station

restricted spatial extension of the river plume and high pelagic primary production in the inner bay (Glé et al. 2008), explaining the spatial patterns in $\delta^{13} \mathrm{C}$ of clam muscles. The hypothesis of selective feeding or selective assimilation against riverine compounds cannot, however, be excluded because it is consistent with the conclusions of Kasai et al. (2004). They indicated that in Japanese coastal habitats, Ruditapes philippinarum consumed mainly marine POM despite the dominance of terrestrial material in the water column. Similar conclusions were given for $R$. decussatus from the Ria Formosa lagoon, Portugal (Machás et al. 2003), and Ria de Arosa (Page \& Lastra 2003).
In contrast, small-scale variability was exemplified by the significant positive correlation between $\delta^{13} \mathrm{C}$ values of clam muscle and tidal elevation. Two hypotheses may explain this: (1) local variation in the contributions of benthic food sources, i.e. microphytobenthos, SOM and associated bacteria, which may vary according to tidal elevation; and/or (2) higher contribution of pelagic sources to the diet of clams located at low tidal levels, since pelagic sources were less ${ }^{13} \mathrm{C}$ enriched than benthic sources (Table 1) (Kang et al. 1999, Kasai et al. 2004, Kanaya et al. 2005, Schaal et al. 2008). Both mechanisms can operate simultaneously because resuspended bacteria may constitute a 
notable contribution to Ruditapes philippinarum diet in Zostera noltii meadows, despite a dominant contribution of phytoplankton (Kharlamenko et al. 2001).

$\delta^{15} \mathrm{~N}$ values of muscle tissue from clams varied by $2.4 \%$ across the bay, exhibiting a south to north decreasing trend with enriched ${ }^{15} \mathrm{~N}$ values in the southeast, near the Leyre River mouth. A similar trend was reported between inner and outer parts of the Ria Formosa lagoon for both muscles and digestive glands of Mytilus galloprovincialis and Ruditapes decussatus (Machás et al. 2003). In contrast, McKinney et al. (2001) found a significant correlation between $\delta^{15} \mathrm{~N}$ in Geukensia demissa mussels and nitrogen derived from anthropogenic activities. As suspension-feeders, Manila clams incorporate diet components linked to primary production, which depend on nutrient inputs within coastal systems. Thus 2 hypotheses could explain $\delta^{15} \mathrm{~N}$ variations in relation to changes in $\delta^{15} \mathrm{~N}$ of nitrogen-loadings in Arcachon Bay: (1) inputs of heavier nitrogen by rivers and streams compared to oceanic waters and (2) spatial variability within the bay in the nitrogen recycling by microbial organisms in the water column and/or sediments.

First, rivers and streams running into Arcachon Bay are fuelled by different nitrogen sources, but relative proportions among atmospheric depositions, fertilizers and wastewaters depend on land use and management policies in the catchment. Intensive agriculture occupies only $9 \%$ of the land-catchment surface but contributes $78 \%$ of the total nitrogen load entering the lagoon, mainly in the form of nitrates (De Wit et al. 2005, Deborde et al. 2008). To prevent eutrophication in the lagoon, all paper mill effluents and human wastewaters have been collected since the 1970s by a sewage collector which diverts treatment plant effluents to the open ocean, $8 \mathrm{~km}$ south of the entrance to the lagoon (De Wit et al. 2005). This results in a negligible influence of wastewater inputs on the nitrogencycling within Arcachon Bay. The influence of fertilizers appears low or spatially restricted to small stream inputs located in the northwestern bay since $\delta^{15} \mathrm{~N}$ of both Leyre River POM and inner bay phytoplankton (Table 1) are similar to those reported in other coastal systems (e.g. Kang et al. 1999, Machás et al. 2003, Page \& Lastra 2003, Kasai et al. 2004).

Secondly, mineralization processes are intense in Arcachon Bay, reflected by the composition of intertidal flats, which consist of muddy sediments enriched in organic matter with pore water containing higher recycled nutrient concentrations (Deborde et al. 2008). These authors estimated that during one year, nutrient exports to the pelagic system by tidal pumping provided about 5 times more ammonium inputs than the freshwater fluxes, which predominantly carried nitrates (De Wit et al. 2005, Deborde et al. 2008). Ac- cording to Glé et al. (2008), seasonal and spatial variation in pelagic primary production in Arcachon Bay is driven by the relative balance between nutrient levels. The highest pelagic primary production rates are observed in spring in the whole bay (outer and inner) following winter nutrient inputs by freshwater runoffs. In contrast, mid-spring to fall primary production is much lower in the outer than the inner bay. During the period of nitrogen-limitation, inner bay production is sustained by ammonium pulses coming from benthic remineralisation. In this context, light $\delta^{15} \mathrm{~N}$ values recorded during the present study in inner bay phytoplankton during spring (Table 1) indicated the uptake of ammonium during a period of nitrate depletion (Cifuentes et al. 1988). At the whole bay scale, these processes are indeed constrained by tidal hydrodynamics and residence time of water masses (Glé et al. 2008) and they may contribute to the spatial variability observed in $\delta^{15} \mathrm{~N}$ clam muscle through the incorporation of spatially distinct labelled $\delta^{15} \mathrm{~N}$ phytoplankton.

\section{Spatial variation in the dietary regime}

The spring dietary regime of Ruditapes philippinarum in Arcachon Bay was dominated by phytoplankton with minor contributions of Zostera noltii and intermediate proportions of SOM. Dominance of phytoplankton in the dietary regime of Manila clams has been shown by other studies (Kharlamenko et al. 2001, Kasai et al. 2004, Kanaya et al. 2005, Yokoyama et al. 2005b). The present study, however, highlighted spatial variation in the dietary regime of $R$. philippinarum within its $70 \mathrm{~km}^{2}$ distribution area in Arcachon Bay. Numerous stable isotope studies of coastal food webs have similarly suggested that spatial changes in trophic structure are common in heterogeneous environments (Stephenson \& Lyon 1982, Deegan \& Garritt 1997, Cloern et al. 2002). Although variability in food resources was buffered by the timeintegrated response of muscle tissues (Tieszen et al. 1983), spatial changes in stable isotope ratios of Manila clams in Arcachon Bay were much lower than those recorded in bivalves inhabiting the estuarine to ocean gradient (Riera \& Richard 1996, Cloern et al. 2002, Page \& Lastra 2003). The present study suggests major differences between the southern and northern parts of the bay in terms of diversity of trophic sources. The proportion of trophic sources gradually changed from almost entirely outer phytoplankton in the south along the Teychan Channel to a more diversified diet regime along the Piquey Channel (Fig. 1). This spatial pattern may be mainly explained by water mass circulation within the bay, as $60 \%$ of oceanic inputs entering the lagoon followed the Teychan Channel versus 15\% for 
the Piquey Channel (Plus et al. 2006). Both $\delta^{13} \mathrm{C}$ and $\delta^{15} \mathrm{~N}$ values of clams located in the south in the vicinity of the Leyre River mouth indicate a major contribution of outer bay phytoplankton during periods of low Leyre River discharge. The network of channels reduces marine inputs to the northern bay, resulting in decreased outer bay phytoplankton availability, and clams thus have to diversify their trophic sources to guarantee their metabolic requirements. Higher contributions of inner bay phytoplankton, riverine POM, microphytobenthos, SOM and $Z$. noltii in the food regime of clams located in the northern bay were also consistent with longer residence times of water masses (Plus et al. 2006), higher numbers of riverine diffuse sources (De Wit et al. 2005) and larger Zostera noltii meadow surfaces (Auby \& Labourg 1996) compared to the southern bay. This is in agreement with numerous studies (e.g. Deegan \& Garritt 1997) which have suggested that benthic primary consumers rely on locally produced food sources in estuarine food webs.

Acknowledgements. We are particularly grateful to P. Lebleu and F. Prince for their assistance in the field; K. Charlier and I. Billy for technical assistance with the elemental analyzer; H. Palvadeau, M. Noury and J. Wienebett for assistance during feeding experiments; G. Paulliac, G. Lamaison and L. Bourasseau for chl a analysis; Y. Descatoire for graphic work; and A. Pothier for unpublished data on stable isotope analyses. C.D. was supported by a grant from Fonds Commun de Coopération Aquitaine-Euskadi and Conseil Général de la Gironde. This study was supported by the Programme National d'Environnement Côtier (PNEC), 'Chantier Littoral Atlantique', the Institut Français pour la Recherche et l'Exploitation de la MER (IFREMER) and the Centre National de la Recherche Scientifique (CNRS).

\section{LITERATURE CITED}

Auby I, Labourg PJ (1996) Seasonal dynamics of Zostera noltii Hornem. in the Bay of Arcachon (France). J Sea Res 35: 269-277

Baud JP, Bacher C (1990) Use of saline ground water for intensive rearing of Ruditapes philippinarum juveniles in a nursery system. Aquaculture 88:157-178

Blanchet H, de Montaudouin X, Lucas A, Chardy P (2004) Heterogeneity of macrozoobenthic assemblages within a Zostera noltii seagrass bed: diversity, abundance, biomass and structuring factors. Estuar Coast Shelf Sci 61:111-123

Bouchet JM (1993) Stratifications, fronts halins dans une lagune mésotidale (Bassin d'Arcachon - France). In: Sorbe JC, Jouanneau JM (eds) $3^{\text {e }}$ Coll Int d'Oceanogr Golfe de Gascogne. Station Marine d'Arcachon, Arcachon, p 33-39

Caill-Milly N, Duclercq B, Morandeau G (2006) Campagne d'évaluation du stock de palourdes du bassin d'Arcachon. Rapp IFREMER, Anglet, p 1-51

Cifuentes LA, Sharp JH, Fogel ML (1988) Stable carbon and nitrogen isotope biogeochemistry in the Delaware estuary. Limnol Oceanogr 33:1102-1115

Cloern JE, Canuel EA, Harris D (2002) Stable carbon and nitrogen isotope composition of aquatic and terrestrial plants of the San Francisco Bay estuarine system. Limnol
Oceanogr 47:713-729

Dang C, de Montaudouin X, Gonzalez P, Mesmer-Dudons N, Caill-Milly N (2008) Brown muscle disease (BMD), an emergent pathology affecting Manila clam Ruditapes philippinarum in Arcachon Bay (SW France). Dis Aquat Org 80:219-228

$>$ De Wit R, Leibreich J, Vernier F, Delmas F and others (2005) Relationship between land-use in the agro-forestry system of les Landes, nitrogen loading to and risk of macro-algal blooming in the Bassin d'Arcachon coastal lagoon (SW France). Estuar Coast Shelf Sci 62:453-465

> Deborde J, Anschutz P, Auby I, Glé C and others (2008) Role of tidal pumping on nutrient cycling in a temperate lagoon (Arcachon Bay, France). Mar Chem 109:98-114

Deegan LA, Garritt RH (1997) Evidence for spatial variability in estuarine food webs. Mar Ecol Prog Ser 147:31-47

DeNiro MJ, Epstein S (1978) Influence of diet on the distribution of carbon isotopes in animals. Geochim Cosmochim Acta 42:495-506

> DeNiro MJ, Epstein S (1981) Influence of diet on the distribution of nitrogen isotopes in animals. Geochim Cosmochim Acta 45:341-351

> Dubois S, Blin JL, Bouchaud B, Lefebvre S (2007) Isotope trophic-step fractionation of suspension-feeding species: implications for food partitioning in coastal ecosystems. J Exp Mar Biol Ecol 351:121-128

Flassch JP, Leborgne Y (1992) Introduction in Europe, from 1972 to 1980, of the Japanese Manila clam (Tapes philippinarum) and the effects on aquaculture production and natural settlement. ICES Mar Sci Symp 194:92-96

Gannes LZ, O'Brien DM, Martínez del Rio C (1997) Stable isotopes in animal ecology: assumptions, caveats, and a call for more laboratory experiments. Ecology 78:1271-1276

Glé C, Del Amo Y, Sautour B, Laborde P, Chardy P (2008) Variability of nutrients and phytoplankton primary production in a shallow macrotidal coastal ecosystem (Arcachon Bay, France). Estuar Coast Shelf Sci 76:642-656

Gosling E (2004) Bivalve molluscs: biology, ecology and culture. Fishing News Books, Blackwell, Oxford

Kanaya G, Nobata E, Toya T, Kikuchi E (2005) Effects of different feeding habits of three bivalve species on sediment characteristics and benthic diatom abundance. Mar Ecol Prog Ser 299:67-78

> Kang CK, Sauriau PG, Richard P, Blanchard GF (1999) Food sources of the infaunal suspension-feeding bivalve Cerastoderma edule in a muddy sandflat of Marennes-Oléron Bay, as determined by analyses of carbon and nitrogen stable isotopes. Mar Ecol Prog Ser 187:147-158

Kasai A, Horie H, Sakamoto W (2004) Selection food sources by Ruditapes philippinarum and Mactra veneriformis (Bivalva: Mollusca) determined from stable isotope analysis. Fish Sci 70:11-20

Kennedy P, Kennedy H, Papadimitriou S (2005) The effect of acidification on the determination of organic carbon, total nitrogen and their stable isotopic composition in algae and marine sediment. Rapid Commun Mass Spectrom 19: 1063-1068

Kharlamenko VI, Kiyashko SI, Imbs AB, Vyshkvartzev DI (2001) Identification of food sources of invertebrates from the seagrass Zostera marina community using carbon and sulfur stable isotope ratio and fatty acid analyses. Mar Ecol Prog Ser 220:103-117

> Langton RW, Winter JE, Roels OA (1977) The effect of ration size on the growth and growth efficiency of the bivalve mollusc Tapes japonica. Aquaculture 12:283-292

> Lorrain A, Paulet YM, Chauvaud L, Savoye N, Donval A, Saout C (2002) Differential $\delta^{13} \mathrm{C}$ and $\delta^{15} \mathrm{~N}$ signatures among 
scallop tissues: implications for ecology and physiology. J Exp Mar Biol Ecol 275:47-61

Lorrain A, Savoye N, Chauvaud L, Paulet YM, Naulet N (2003) Decarbonation and preservation method for the analysis of organic $\mathrm{C}$ and $\mathrm{N}$ contents and stable isotope ratios of low-carbonated suspended particulate material. Anal Chim Acta 491:125-133

Machás R, Santos R, Peterson B (2003) Tracing the flow of organic matter from primary producers to filter feeders in Ria Formosa Lagoon, southern Portugal. Estuaries 26: 846-856

Malet N, Sauriau PG, Faury N, Soletchnik P, Guillou G (2007) Effect of seasonal variation in trophic conditions and the gametogenic cycle on $\delta^{13} \mathrm{C}$ and $\delta^{15} \mathrm{~N}$ levels of diploid and triploid Pacific oysters Crassostrea gigas. Mar Ecol Prog Ser 346:203-217

Mann R (1979) The effect of temperature on growth, physiology, and gametogenesis in the Manila clam Tapes philippinarum. J Exp Mar Biol Ecol 38:121-133

McCutchan JHJ, Lewis WMJ, Kendall C, McGrath CC (2003) Variation in trophic shift for stable isotope ratios of carbon, nitrogen, and sulfur. Oikos 102:378-390

McKinney RA, Nelson WG, Charpentier MA, Wigand C (2001) Ribbed mussel nitrogen isotope signatures reflect nitrogen sources in coastal salt marshes. Ecol Appl 11: 203-214

Page HM, Lastra M (2003) Diet of intertidal bivalves in the Ría de Arosa (NW Spain): evidence from stable C and N isotope analysis. Mar Biol 143:519-532

Paulet YM, Lorrain A, Richard J, Pouvreau S (2006) Experimental shift in diet $\delta^{13} \mathrm{C}$ : a potential tool for ecophysiological studies in marine bivalves. Org Geochem 37:1359-1370

Peterson BJ, Fry B (1987) Stable isotopes in ecosystem studies. Annu Rev Ecol Syst 18:293-320

Phillips DL, Gregg JW (2003) Source partitioning using stable isotopes: coping with too many sources. Oecologia 136: 261-269

Phillips DL, Newsome SD, Gregg JW (2005) Combining sources in stable isotope mixing models: alternative methods. Oecologia 144:520-527

Plus M, Maurer D, Stanisière JY, Dumas F (2006) Caractérisation des composants hydrodynamiques d'une lagune mésotidale, le bassin d'Arcachon. Rapp IFREMER Arcachon, R.INT.DIR/LAB/SERV AN, p 1-58

Post DM (2002) Using stable isotopes to estimate trophic posi-

Editorial responsibility: Katherine Richardson,

Copenhagen, Denmark tion: models, methods, and assumptions. Ecology 83: 703-718

Riera P, Richard P (1996) Isotopic determination of food sources of Crassostrea gigas along a trophic gradient in the estuarine bay of Marenne-Oléron. Estuar Coast Shelf Sci 42:347-360

> Robert R, Trut G, Laborde JL (1993) Growth, reproduction and gross biochemical composition of the Manila clam Ruditapes philippinarum in the Bay of Arcachon, France. Mar Biol 116:291-299

> Sauriau PG, Haure J, Baud JP (1997) Sprinkling: a new method of distributing live algae food in marine coastal ponds used for Manila clam Tapes philippinarum (Adams \& Reeve) intensive culture. Aquac Res 28: 661-669

Schaal G, Riera P, Leroux C (2008) Trophic coupling between two adjacent benthic food webs within a man-made intertidal area: a stable isotopes evidence. Estuar Coast Shelf Sci 77:523-534

Sokal RR, Rohlf FJ (1981) Biometry. WH Freeman, New York

> Stephenson RL, Lyon GL (1982) Carbon-13 depletion in an estuarine bivalve: detection of marine and terrestrial food sources. Oecologia 55:110-113

> Tieszen LL, Boutton TW, Tesdahl KG, Slade NA (1983) Fractionation and turnover of stable carbon isotopes in animal tissues: implication for $\delta^{13} \mathrm{C}$ analysis of diet. Oecologia 57: $32-37$

Vander Zanden MJ, Rasmussen JB (2001) Variation in $\delta^{15} \mathrm{~N}$ and $\delta^{13} \mathrm{C}$ trophic fractionation: implications for aquatic food web studies. Limnol Oceanogr 46:2061-2066

- Vanderklift MA, Ponsard S (2003) Sources of variation in consumer-diet $\delta^{15} \mathrm{~N}$ enrichment: a meta-analysis. Oecologia 136:169-182

Yentsch CS, Menzel DW (1963) A method for the determination of phytoplankton chlorophyll and pheophytin by flurorescence. Deep-Sea Res 10:221-231

> Yokoyama H, Tamaki A, Harada K, Shimoda K, Koyama K, Ishihi Y (2005a) Variability of diet-tissue isotopic fractionation in estuarine macrobenthos. Mar Ecol Prog Ser 296: $115-128$

Yokoyama H, Tamaki A, Koyama K, Ishihi Y, Shimoda K, Harada K (2005b) Isotopic evidence for phytoplankton as a major food source for macrobenthos on an intertidal sandflat in Ariake Sound, Japan. Mar Ecol Prog Ser 304: 101-116

Submitted: November 6, 2008; Accepted: May 11, 2009

Proofs received from author(s): July 7, 2009 